\title{
Witnesses of the early Pliocene sea-level rise in the Manilva Basin (Málaga, S Spain)
}

\author{
Julio AGUIRRE ${ }^{\prime *}$, Rosa DOMÈNECH ${ }^{2}$, Jordi MARTINELL ${ }^{2}$, Eduardo MAYORAL ${ }^{3}$, Ana \\ SANTOS ${ }^{3}$ \& José Noel PÉREZ-ASENSIO
}

${ }^{1}$ Dpto. Estratigrafía y Paleontología, Facultad de Ciencias, Campus de Fuentenueva s.n. Universidad de Granada, 18002 Granada (Spain); jaguirre@ugr.es

${ }^{2}$ IRBio (Biodiversity Research Institute) and Dpt. d'Estratigrafia, Paleontologia i Geociències Marines, Universitat de Barcelona, Martí Franquès s/n, E-08028 Barcelona (Spain); rosa.domenech@ub.edu; jmartinell@ub.edu

${ }^{3}$ Dpto. Ciencias de la Tierra, Facultad de Ciencias Experimentales, Universidad de Huelva, Campus de El Carmen, Avd. 3 de Marzo, s/n, 21071 Huelva (Spain); mayoral@uhu.es; aasantos@ugr.es

${ }^{4}$ GRC Geociències Marines, Departament de Dinàmica de la Terra i de l'Oceà, Facultat de Ciències de la Terra, Universitat de Barcelona, Carrer Martí i Franquès s/n, 08028 Barcelona (Spain); jn.perezasensio@ub.edu

* Corresponding author

Aguirre, J., Domènech, R., Martinell, J., Mayoral, E., Santos, A. \& Pérez-Asensio, J.N. 2017. Witnesses of the early Pliocene sea-level rise in the Manilva Basin (Málaga, S Spain). [Testigos de la transgresión del Plioceno inferior en la Cuenca de Manilva (Málaga, S de España)]. Spanish Journal of Palaeontology, 32 (1), 35-52.

\section{ABSTRACT}

The Sierra de la Utrera, a relief in the Manilva Basin (Málaga, SW Spain), shows bored surfaces at different heights above present-day sea level, from $96 \mathrm{~m}$ to $287 \mathrm{~m}$. Borings occur in the eastern, central, and western parts of the Canuto de la Utrera, a prominent gorge in the central-southern part of the relief excavated in Mesozoic limestones, as well as on the western end of the Canuto Chico, a smaller canyon in the northern part. Pliocene marine deposits fossilized the bored surfaces. Bored boulders of the substrate are embedded in the Pliocene sediments. The traces Gastrochaenolites ispp., Entobia ispp., Caulostrepsis ispp., Circolites kotoucensis, and Ericichnus asgaardi have been identified. Among these, Caulostrepsis is found only in the reworked blocks. This ichnoassemblage, attributed to the archetypical Entobia Ichnofacies of rocky shores, represents boring activity in high-energy, very-shallow-water settings, close to the sea level, and with a virtually null sedimentation rate. The vertical

\section{RESUMEN}

La Sierra de la Utrera es un relieve Penibético situado en la Cuenca de Manilva (Málaga, SO de España) que presenta superficies bioperforadas a diferentes alturas, desde $96 \mathrm{~m}$ hasta $248 \mathrm{~m}$. Las bioperforaciones se encuentran en las zonas oriental, central y occidental del Canuto de la Utrera, una garganta fluvial en la zona centro-sur de la sierra excavada en calizas del Mesozoico, en el extremo occidental del Canuto Chico, un cañón más pequeño en la zona septentrional del relieve. Las perforaciones están fosilizadas por depósitos marinos del Plioceno. Bloques erosionados del substrato y redepositados en los materiales pliocenos también presentan perforaciones. Se han identificado Gastrochaenolites ispp., Entobia ispp., Caulostrepsis ispp., Circolites kotoucensis, y Ericichnus asgaardi. De todas ellas, las trazas de Caulostrepsis se encuentran exclusivamente en los bloques erosionados del substrato. El contenido icnológico, perteneciente a la Icnofacies de Entobia de costas rocosas, se produjo en ambientes muy 
distribution of bored surfaces attests to a progressive sea-level rise. The onlap of the Pliocene deposits on the substrate is consistent with the deepening trend. Planktonic foraminiferal assemblages collected from the sediment adjacent to the Sierra de la Utrera demonstrate that boring activity spanned, at most, 1 Ma during the early Pliocene, Zanclean (biozones MPl 1 and MP1 2), ranging from 5.33 to $4.36 \mathrm{Ma}$. Benthic foraminiferal assemblages indicate oligotrophic, well-oxygenated, deepwater conditions bordering the substrate. The presence of nearly vertical, deep submarine cliffs surrounding the relief accounts for these conditions very close to the substrate.

Keywords: Bioerosion, Entobia ichnofacies, palaeogeography, early Pliocene transgression, Sierra de la Utrera. someros, próximos al nivel del mar, de alta energía y con una tasa de sedimentación muy baja o nula. La distribución vertical de las bioperforaciones indica que se formaron durante una subida de nivel del mar. Una disposición de solapamiento expansivo de los sedimentos pliocenos confirma dicha profundización. Las asociaciones de foraminíferos planctónicos de los sedimentos adyacentes a la Sierra de la Utrera indican que la actividad bioperforadora se prolongó $\sim 1$ Ma durante el Plioceno inferior, Zancliense (biozonas MP11 y MP12), entre 5.33 y $4.36 \mathrm{Ma}$. Por su parte, los foraminíferos bentónicos indican un ambiente oligotrófico, bien oxigenado, y de aguas profundas en las inmediaciones del relieve. La existencia de acantilados submarinos profundos rodeando el relieve explicaría dichas condiciones paleoambientales próximas al substrato.

Palabras clave: Bioerosión, icnofacies de Entobia, paleogeografía, transgresión del Plioceno inferior, Sierra de la Utrera.

\section{INTRODUCTION}

Rocky shores are particular settings of great geological interest in the transition from the land to the sea but they have been traditionally overlooked by geologists (Johnson, 1988a, 1988b). Successive compilations of ancient rocky shore examples in the last decades have shown an increase in works dealing with, or particularly focusing on, these environments (Johnson, 1988a, 1988b; Johnson \& Baarli, 1999, 2012). Although deposition associated with coastal cliffs can take place in relatively deep waters (several tens of meters of water depth), the identification of rocky shores has been conventionally used to delineate past shorelines. This, in turn, is critical to investigate sea-level and palaeogeographic changes, as well as the tectonic evolution of palaeocoasts.

Among the criteria compiled by Johnson (1988b) and Johnson \& Baarli (2012) to recognize ancient rocky shores, only one deals with the biota inhabiting these settings. The characteristic components of modern communities dwelling on rocky shores, at high taxonomic levels, appeared by the late Oligocene and, since then, these communities have remained almost unchanged (Aguirre \& Jiménez, 1997; Johnson \& Baarli, 2012). Particularly valuable components to characterise fossil assemblages of rocky shores are boring organisms (e.g. Taylor \& Wilson, 2003). Bioerosion constitutes conclusive evidence of the activity of organisms that inhabited ancient rocky coasts, since their remains are often preserved in situ and, for a taxonomically diverse biota, it represents the only way to be preserved in the geological record (Tapanila, 2008; Gibert et al., 2012). One of the main utilities of bored surfaces in ancient rocky shores is the identification of palaeoshorelines.
According to the recent compilation of literature on fossil rocky-shore deposits (Johnson \& Baarli, 2012), Neogene and Quaternary examples are by far the most abundant and the best documented ones. In the Iberian Peninsula in particular, there is a wealth of studies dealing with boring ichnoassemblages in Neogene rocky shores (Martinell \& Domènech, 1986; Silva et al., 1995; Aguirre \& Jiménez, 1997; Gibert et al., 1998; Silva et al., 1999; Domènech et al., 2001; Cachão et al., 2009; Santos et al., 2008a, 2010, 2011a; Gibert et al., 2012; Aguirre et al., 2014; Domènech et al., 2014; Rodríguez-Tovar et al., 2015).

In the Sierra de la Utrera, located in the Manilva Basin (SW Spain) (Fig. 1), well-documented examples of boring ichnoassemblages associated with rocky-shore settings have been reported (Santos et al., 2008b; Martinell et al., 2008). This relief was covered by Pliocene marine deposits, which also include bored boulders and big blocks derived from the substrate. In this paper, a detailed characterization of the boring ichnoassemblages, both those preserved in situ in the substrate and those found in the fallen blocks, is presented. The in situ preserved bored surfaces documented sea-level variations that, in turn, enabled palaeogeographic changes to be delineated in the basin. In addition, bored boulders eroded away from the basement and embedded in the surrounding Pliocene deposits recorded the successive boring activity affecting the substrate during the sea-level change.

The aims of the present study are: 1) to characterise the ichnoassemblages preserved in situ in the substrate and those found in the redeposited boulders; 2) to use bioerosion structures to delineate relative sea-level variations as well as palaeogeographic changes in the study area; 3) to constraint the timing involved in the sealevel change in the Manilva Basin; and 4) to determine the role of the sea-level oscillations in the palaeogeographic evolution during the studied time interval. 

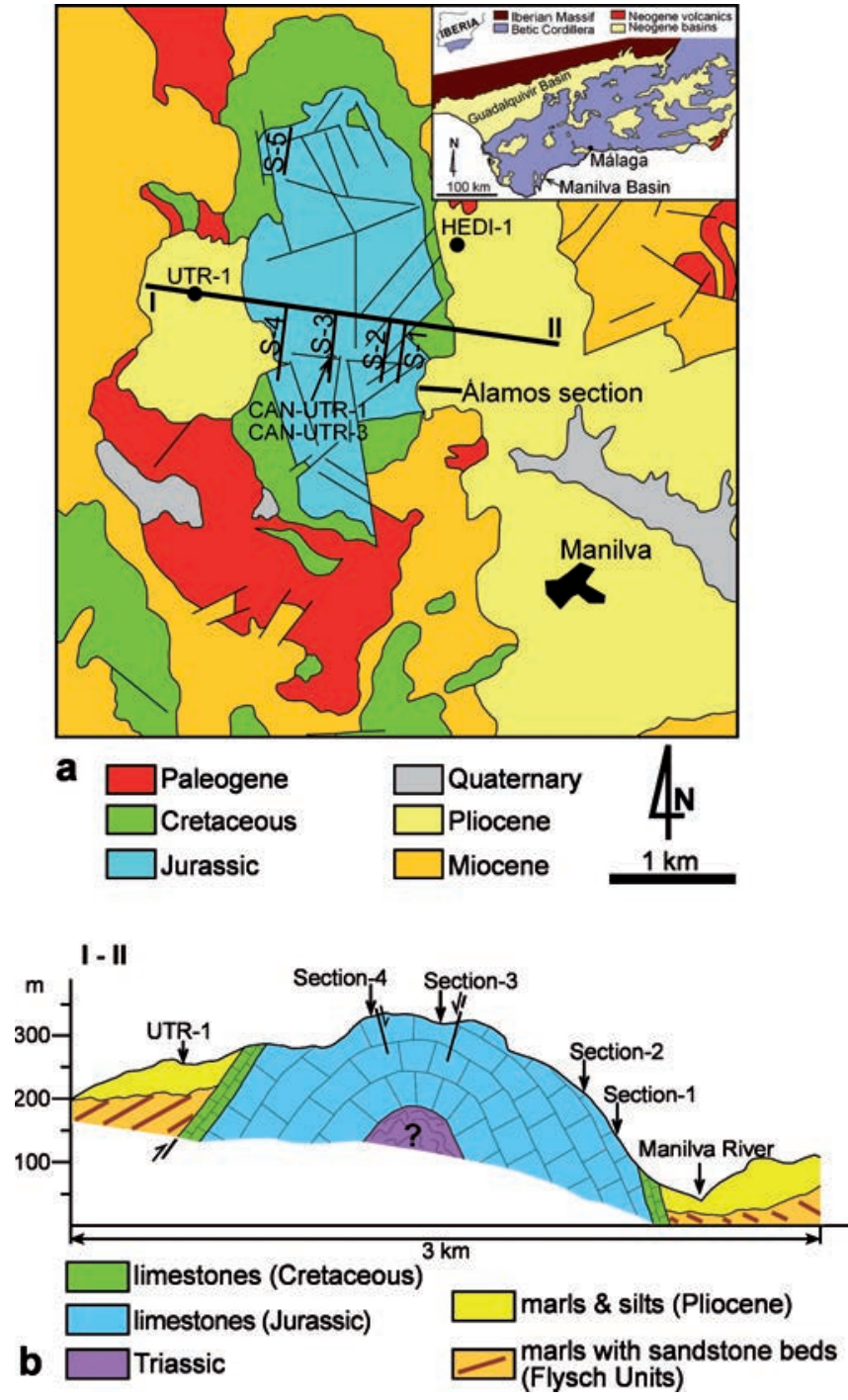

Figure 1. a) Location and geological map of the Sierra de la Utrera and its environs. The transect I-II represents the cross-section shown in (b). S-1 to S-5 indicate the positions of the study sections with in situ borings (see Fig. 4). HEDI-1, CAN-UTR-1 to CAN-UTR-3, and UTR-1 show the position of the samples collected for the study of the foraminiferal assemblages. The small Pliocene outcrop indicated by the samples CAN-UTR-1 to CAN-UTR-3 is also the place of the stratigraphic log called Canuto (see Fig. 5). b) Cross section along the transect I-II in (a) indicating the position of Section 1 to Section 4 along the Canuto de la Utrera (see Fig. 4).

\section{LOCATION AND GEOLOGICAL CONTEXT}

The study area is Sierra de la Utrera (also known as Sierra de los Canutos), a relief with a maximum height of 354 $\mathrm{m}$ above present-day sea level, between Casares, to the north, and Manilva, to the south, in the so-called Manilva
Basin (Málaga province, SW Spain) (Fig. 1a). The Sierra de la Utrera is a Jurassic-Cretaceous intensely karstified relief forming an ample N-S oriented anticline (Fig. 1b). Sierra de la Utrera is affected by an intricate set of joints and faults oriented in different directions, prevailing $\mathrm{N} 45$ $50^{\circ} \mathrm{E}$ and $\mathrm{N} 120-145^{\circ} \mathrm{E}$ (Fig. 1a). This complex structural system mostly controlled the karstification of the relief (Zotano, 2003).

In the central-southern part of the Sierra de la Utrera, the relief is cut by a conspicuous E-W gorge with nearly vertical walls called Canuto de la Utrera (or Canuto Grande) excavated following a normal fault (Zotano, 2003; Sendra et al., 2013) (Fig. 2a). A less-prominent E-W canyon lies in the northern part of the relief, the so-called Canuto Chico (Fig. 2b). "Canuto" is a local term used for a marked canyon excavated in a hard substratum, in this case Jurassic-Cretaceous limestones.

The Sierra de la Utrera is the most south-western relief of the External Zones of the Betic Cordillera, the westernmost peri-Mediterranean Alpine belt (MartínAlgarra, 1987). Within the External Zones, the Sierra de la Utrera belongs to the Penibetic Zones, a tectonopalaeogeographic domain of the Betic Cordillera located in the most distal position with respect to the southern palaeomargin of the Iberian Plate (Martín-Algarra, 1987).
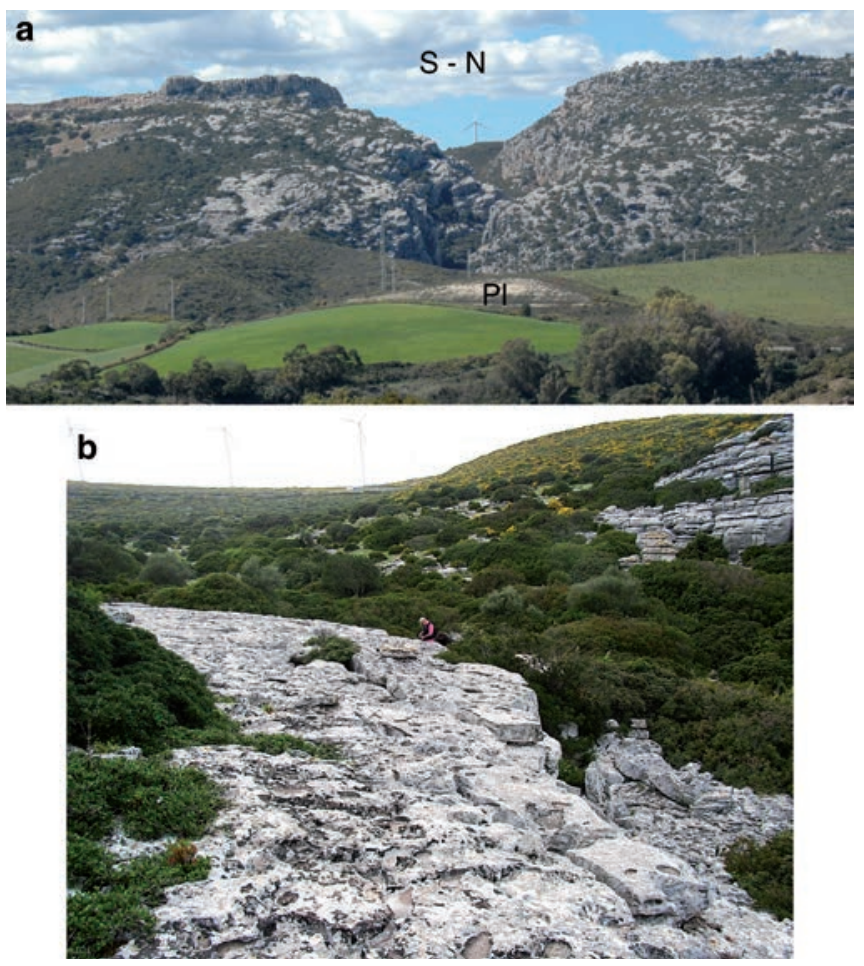

Figure 2. a) Panoramic view of the Canuto de la Utrera at its eastern end (picture taken looking to the west). Yellowish sediments in the foreground (P1) are Pliocene deposits. b) Panoramic view of the Canuto Chico (the photo is taken looking to the WNW). 
The outcropping nucleus of the Sierra de la Utrera anticline is made up of Jurassic limestones of the Líbar Group that includes the Endrinal Formation in the lower part (Early-Middle Jurassic) and the Torcal Formation in the upper part (middle Oxfordian-early Valanginian) (Martín-Algarra, 1987) (Fig. 3). Early-Late Cretaceous marly limestones and marls (González-Donoso et al., 1983) of the Espartina Group surround the anticline nucleus (Martín-Algarra, 1987) (Fig. 3). Paleogene limestones, sandy limestones, and marls crop out locally in the vicinity of the Sierra de la Utrera overlying the Mesozoic substrate
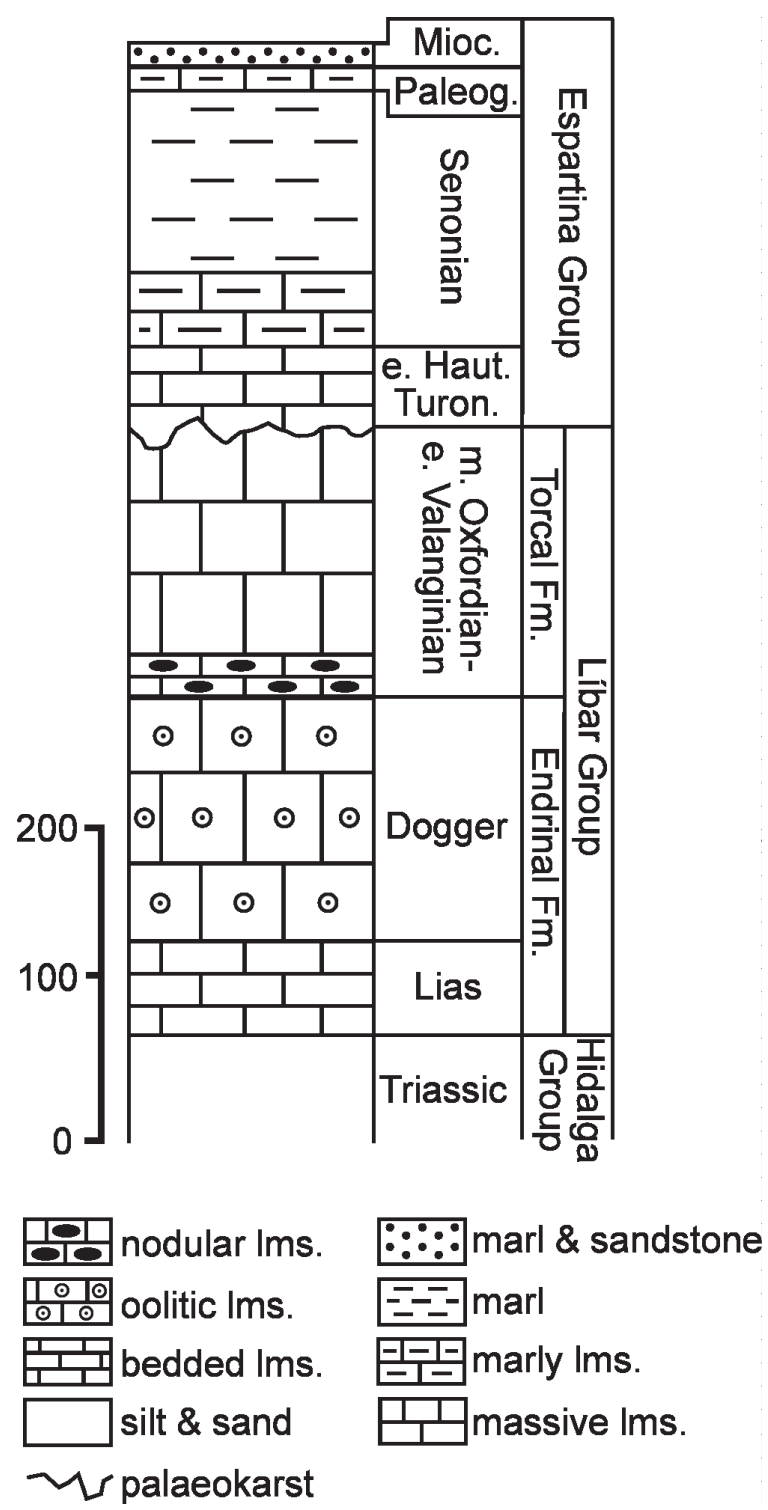

Figure 3. Synthetic stratigraphic log of the Sierra de la Utrera (modified after Martín-Algarra, 1987). The in situ borings affected the limestones of the Líbar Group as well as the limestones and marly limestones of the lower part of the Espartina Group. lms: limestone; Fm.: Formation; e.: early; m.: middle; Haut.-Turon.: Hauterivian-Turonian; Paleog.: Paleogene; Mioc.: Miocene.
(Fig. 3). Turbiditic sandstones alternating with marls of the Campo de Gibraltar Units overthrust the Mesozoic materials (Figs 1, 3). Finally, Pliocene marine deposits unconformably onlap an erosional surface excavated in the previous materials (Fig. 1).

\section{MATERIALS AND METHODS}

As indicated above, this study analyses the bored surfaces found in Sierra de la Utrera, focusing on the ichnoassemblages. Four N-S transects crossing the bored surfaces in the Canuto de la Utrera and one in the Canuto Chico were analysed in order to characterize the ichnoassemblages (Fig. 4). In addition to the bored surfaces in the Mesozoic substrate of the Sierra de la Utrera, bored boulders eroded away from the basement and deposited in the Pliocene materials have also been studied.

The bored surfaces are covered by Pliocene sediments and thus several samples were collected in order to analyse foraminiferal assemblages (Fig. 1a). Planktonic foraminifera provide the biostratigraphic framework of the Pliocene deposits adjacent to the bored substrate, thus allowing an estimation of the time lapse involved in the boring activity. Benthic foraminiferal assemblages, microhabitat preferences and planktonic/benthic ratio (P/B ratio) are useful to infer the palaeoenvironmental conditions in which the Pliocene sediments were formed.

As a means of completing the description of the Pliocene sediments filling up the Manilva Basin, two sections were logged (Fig. 5): one located in the eastern margin of the Sierra de la Utrera, Álamos section, and another in the centre of the Canuto de la Utrera, Canuto section (Fig. 1).

\section{PLIOCENE DEPOSITS IN THE MANILVA BASIN}

The Manilva Basin was a relatively narrow and restricted embayment open to the Mediterranean Sea that roughly follows the present-day fluvial valley of the Manilva River (Fig. 6). This basin configuration resembles other Pliocene basins located along the Málaga coast (Aguirre, 2000; Aguirre et al., 2005) (Fig. 6).

The sedimentary filling of the Manilva Basin consists of Pliocene marine deposits that covered the bored surfaces. The thickness of the Pliocene succession is greater in the eastern part of the Sierra de la Utrera $(\sim 100 \mathrm{~m})$ than in the western side $(\sim 50 \mathrm{~m})$. Surrounding the Sierra de la Utrera, the base of the Pliocene is not observed and the lowermost outcropping sediments are dark-grey clays, 

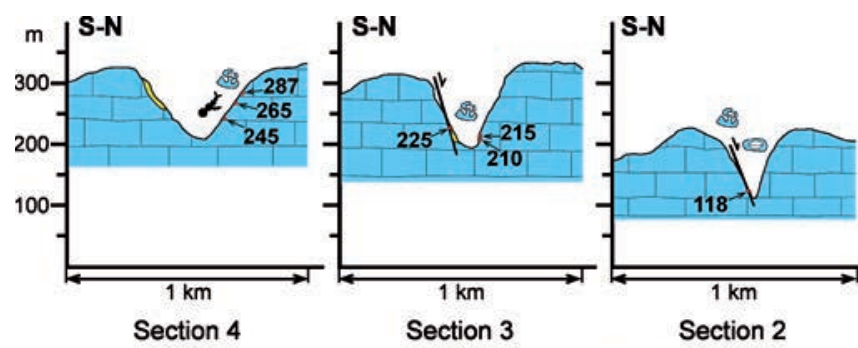

Section 3

Canuto de la Utrera

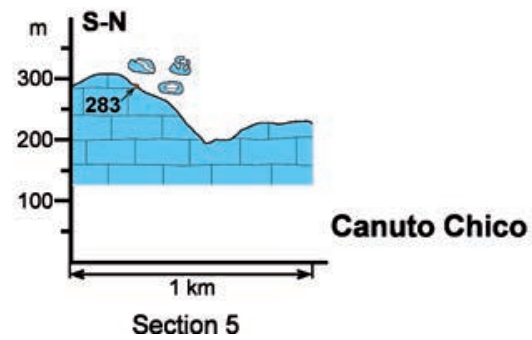

$1 \mathrm{~km}$
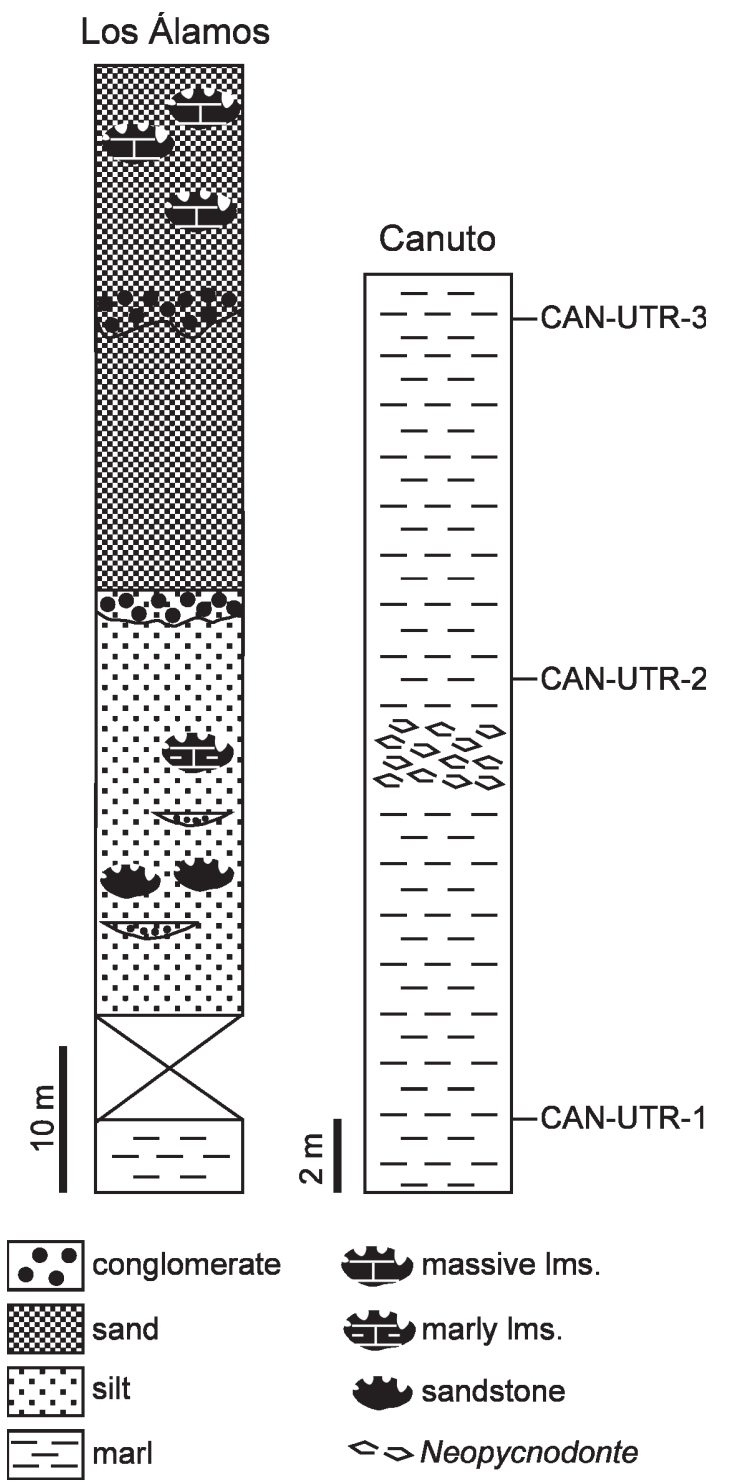

Figure 5. Stratigraphic logs of the Los Álamos and Canuto sections indicating the position of the three samples collected in the latter section. lms.: limestone.
Figure 4. The studied sections in the Canuto de la Utrera (Section 1 to Section 4) and in Canuto Chico (Section 5) with an indication of the heights above present-day sea level of the bored surfaces and the main trace fossils. The position of each section is indicated in Fig. 1a. visible at La Hedionda spring (Figs 1, 7a). Upwards, the clays change gradually to silts, but due to the outcrop conditions, the section cannot be followed beyond this point. South of La Hedionda, in the Álamos section (Figs $1,5)$, the sediments change gradually upwards from silts to medium-grained sands and finally to coarse-grained sands (Figs 5, 7b). Channelled conglomerate and breccia beds are intercalated in the sands in the upper half part of the section (Figs 5, 7c). Conglomerates and breccia are made up mainly of clasts of sandstones of the Flysch Units, Mesozoic limestones, as well as peridotites, schists, and quartzites coming from the Alpujárrides Complex. Large isolated boulders, up to a meter in maximum diameter, of sandstones, limestones, and marly limestones derived from the Betic basement of the Sierra de la Utrera occur dispersed in the sands (Figs 5, 7d-7f). These boulders are found only in the Pliocene deposits of the eastern part of the Sierra de la Utrera, in the Álamos section (Fig. 5). Sandstone blocks deriving from the Flysch Units are the first ones appearing in the stratigraphic succession. Higher up, Cretaceous marly limestones occur. Finally, in the upper half part of the section, boulders of Jurassic limestones are the only ones observed (Fig. 5).

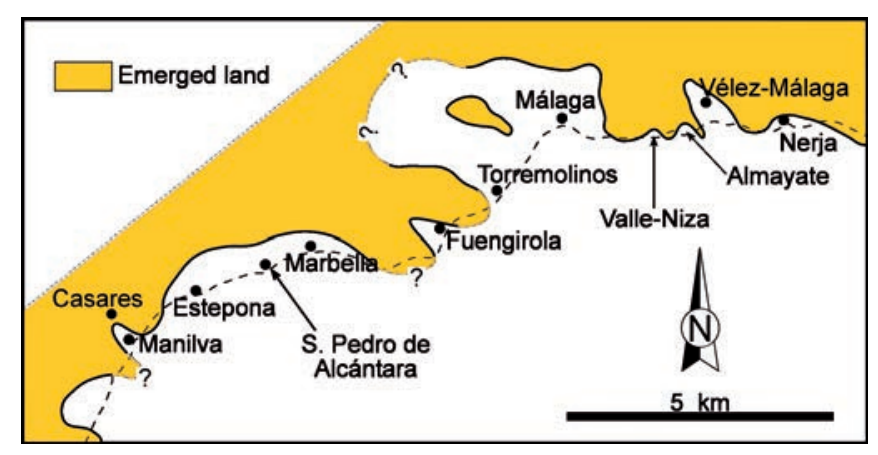

Figure 6. Palaeogeographic map of the Málaga coast inferred for the early Pliocene (modified after Aguirre et al., 2005). 

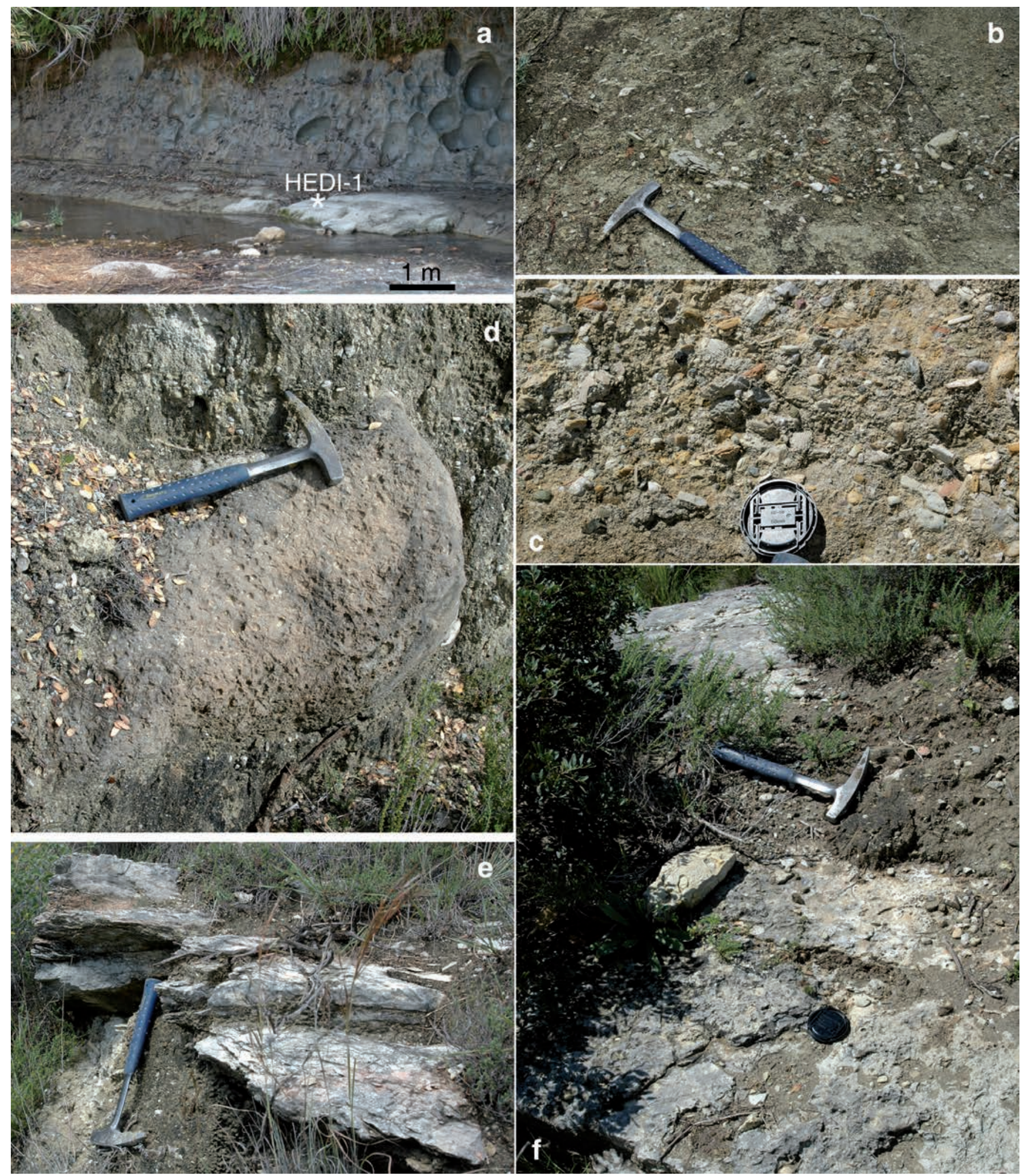

Figure 7. Images of the Pliocene materials studied (a-c) and isolated big boulders embedded in the Pliocene deposits at Álamos section (d-f). a) Blue marls of the lowermost outcropping Pliocene deposits at La Hedionda spring. The asterisk indicates the position of the sample HEDI-1. b) Silts and fine-grained sands with small channelled conglomerates in the lower half part of the Álamos section. c) Conglomerate and breccia of the upper part of the Álamos section. Clasts are sedimentary rocks coming from the basement of the Sierra de la Utrera and metamorphic rocks (schists, quartzites, and peridotites) deriving from the Alpujárrides Complex of Sierra Bermeja, further to the NNW of the study area. d) Bored block of the Miocene Flysch Units. e) Bored block belonging to the Lower Cretaceous marly limestones. f) Two bored blocks of Jurassic massive limestones. 
In the Canuto section (Fig. 5), Pliocene deposits abut the Jurassic limestones (Fig. 8a). They consist of light brownish-yellowish marls with abundant marine fossils (solitary corals, bivalves, brachiopods, and barnacles) (Figs 8b-8d).

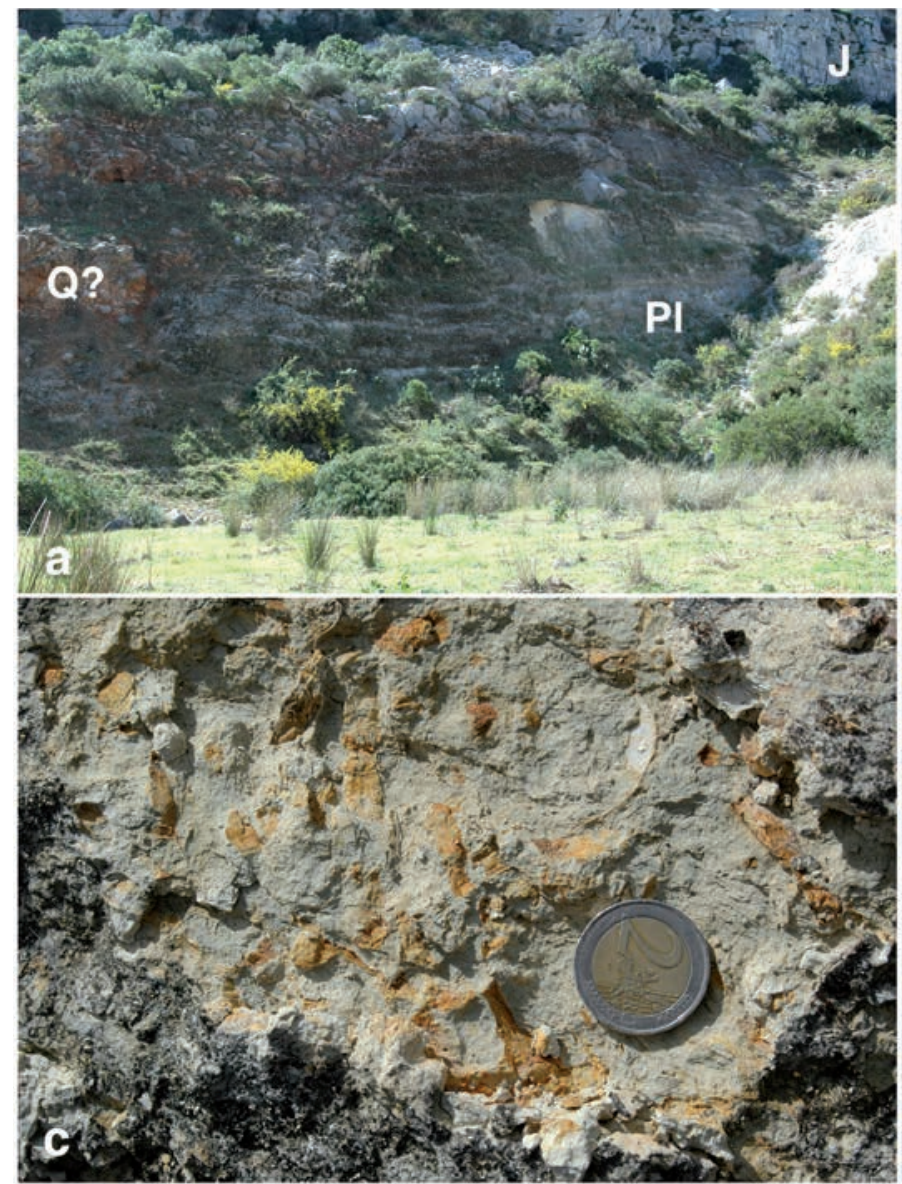

\section{ICHNOFOSSIL ASSEMBLAGES}

Ichnodiversity in the study area is low, both in number of ichnotaxa and in dominance. Only five ichnotaxa were recognised, Entobia ispp., Caulostrepsis ispp., Gastrochaenolites ispp., Circolites kotoucensis, and

Figure 8. a) Panoramic view of the Canuto section in the centre of the Canuto de la Utrera. J: Jurassic limestones; Pl: Pliocene; Q?: possible Quaternary breccia. b-c) Concentration of solitary corals in the marls of the Canuto section. d) Barnacle colonizing shells of Neopycnodonte from the middle part of the Canuto section.

Ericichnus asgaardi (Fig. 9), with Gastrochaenolites leaving the most conspicuous traces. Gastrochaenolites, Entobia, and Caulostrepsis were identified at ichnogenus level (Figs 9a-9d), although several ichnospecies could be present. Unfortunately, the low preservation degree of the majority of borings precluded a finer identification, especially regarding Entobia, the most superficial trace (Fig. 9c).

Among bivalve borings, some specimens were tentatively assigned to the ichnospecies Gastrochaenolites torpedo and G. lapidicus. Although complete specimens were rare, the trend to a perpendicular disposition of Gastrochaenolites to the wall was clear (Figs 9a-9b). Their maximum measurable diameter was $1.5 \mathrm{~cm}$ in average, with small diameters at the lower part of the gorge and

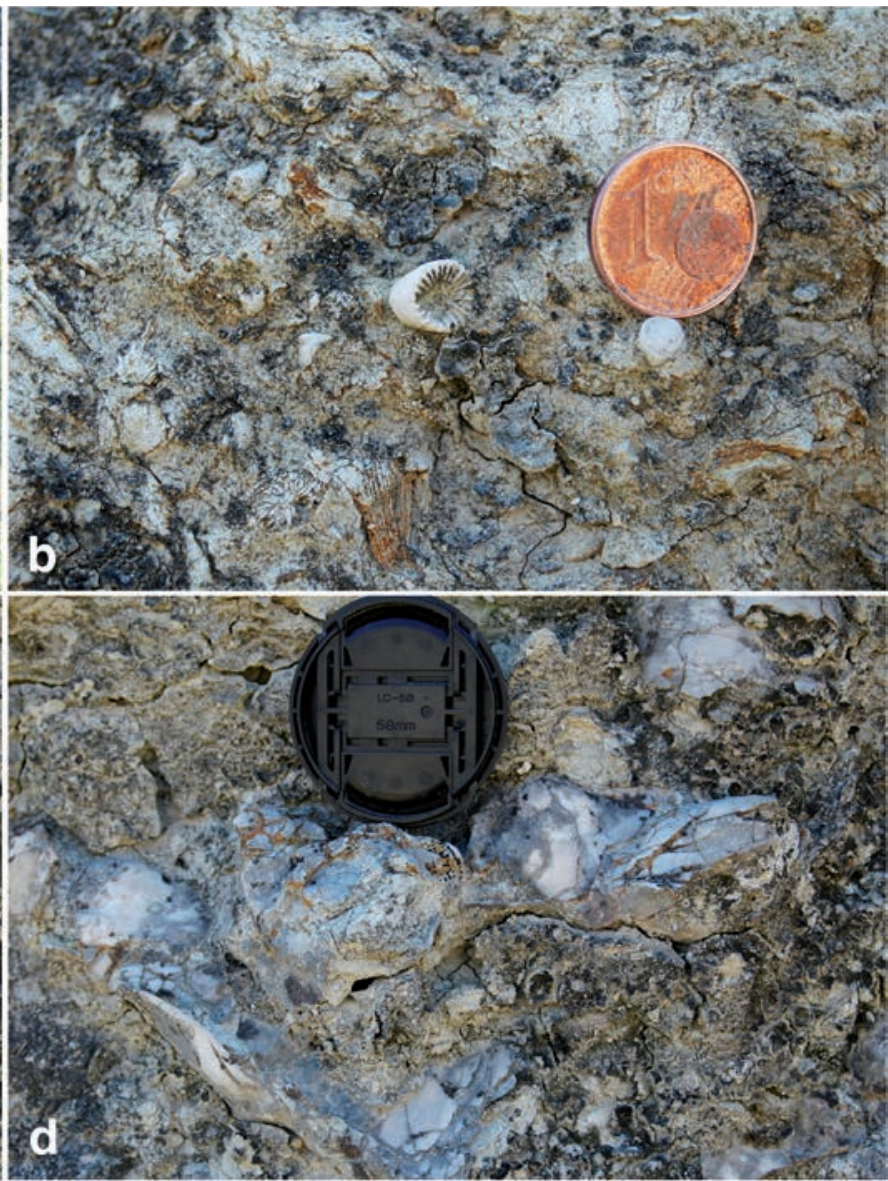



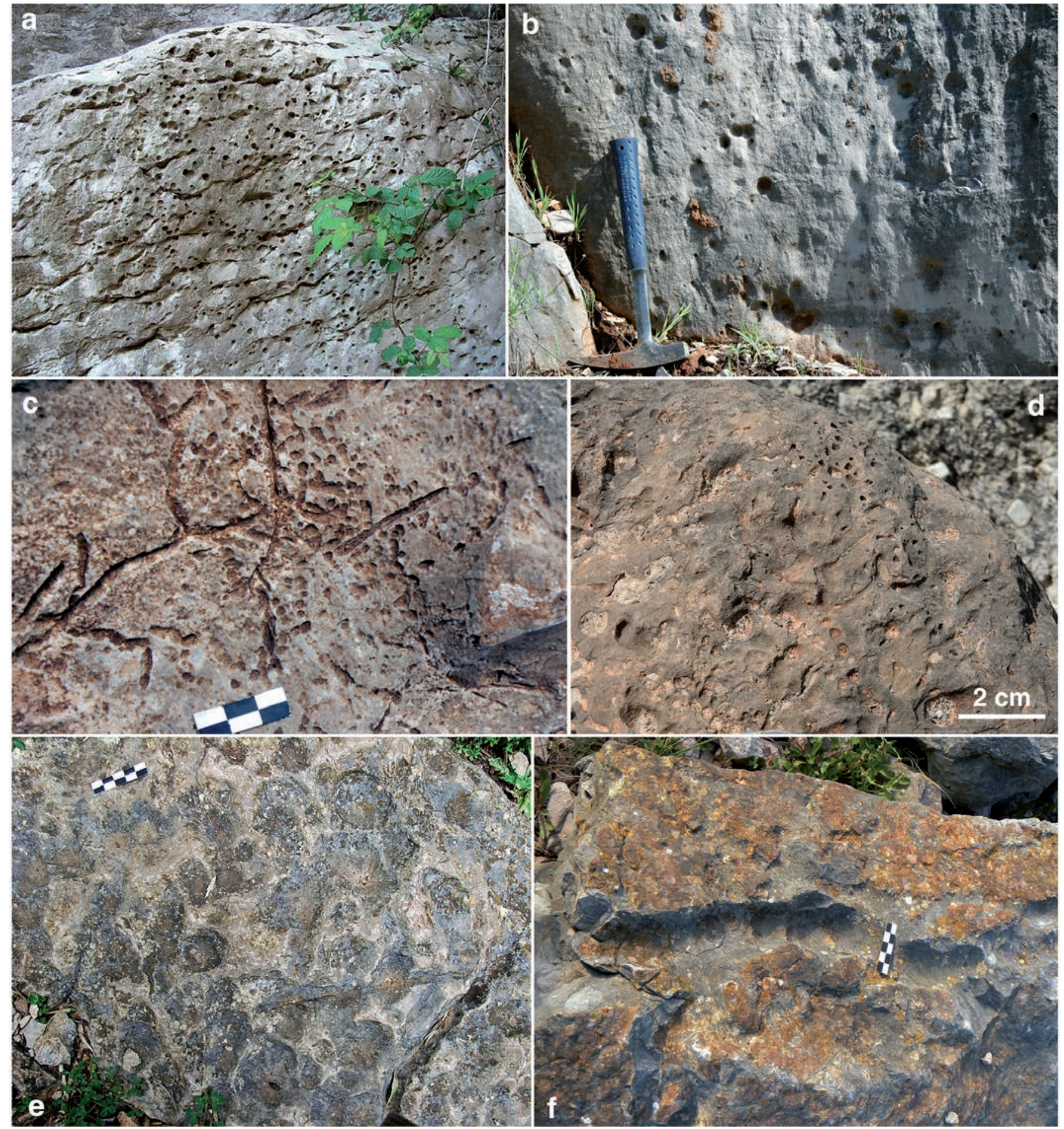

Figure 9. Ichnofossils of the study sections. a) Jurassic calcareous basement with abundant Gastrochaenolites ispp. (Canuto de la Utrera; Section 1). Height of the bored surface is ca. $2 \mathrm{~m}$. b) Gastrochaenolites ispp. in the northern side of the centre of the Canuto de la Utrera (Canuto de la Utrera; Section 3). c) Extended network of Entobia ispp. (Canuto de la Utrera; Section 2). d) Bored block at Álamos section embedded in the Pliocene sediments with Gastrochaeonolites and Caulostrepsis ispp. e) Concentration of Circolites kotoucensis (Canuto de la Utrera; Section 2). f) Ericichnus asgaardi from the Canuto Chico (Section 5).

former being present in both Canuto de la Utrera and Canuto Chico. As indicated above, the Sierra de la Utrera is intensely karstified; therefore weathering sometimes blurred the profile of the echinoid traces, making it difficult to distinguish them from inorganic erosive processes. Nonetheless, several pieces of evidence account for their biological origin. 1) The morphology. The traces of Ericichnus and Circolites were exactly identical to those 
found in very different geographical areas, such as the island of Santa Maria, in the archipelago of the Azores, the island of Sal, in the archipelago of Cape Verde (Santos et al., 2015; Santos \& Mayoral, 2016), and in the rocky coast of Salou (Tarragona) (Belaústegui et al., in press). 2) The distribution. The echinoid traces were not randomly distributed. If the morphological structures attributed here to echinoid traces were the result of different types of karren, a more homogeneous and pervasive distribution would be expected. Nonetheless, the traces occurred in particular stratigraphic positions, invariably associated with other biological structures, such as Gastrochaenolites. 3) The orientation. The erosive structures followed the dominant fault and joint systems oriented predominantly $\mathrm{N} 45-50^{\circ}$ E and N $120-145^{\circ}$ E that shaped the Sierra de la Utrera. However, traces attributed to Ericichnus showed an $\mathrm{N} 65-70^{\circ} \mathrm{E}$ preferential orientation, indicating that they are most likely biological but not karstic dissolution following the preexisting main fracturing systems. Clearly, these arguments account for the traces that we attribute to echinoid activity. Other similar, although more questionable, traces are not considered here. This means that the actual presence of echinoid borings could be even higher than here is considered, since only unequivocal depressions of organic origin were taken into account. Hemispherical depressions corresponding to $C$. kotoucensis appeared isolated or in groups of more than 8 specimens, and had an average diameter of $\sim 3.5 \mathrm{~cm}$ (Fig. 9e). E. asgaardi had single groove morphology with irregular paths up to $35 \mathrm{~cm}$ in observable length with a variable width between 4 and $7 \mathrm{~cm}$ (Fig. 9f). Enlargements along the grooves corresponded to their associated Circolites, as described by Santos et al. (2015).

As stated above, Caulostrepsis appeared only in fallen blocks, so that it was not possible to certify its position within the sections. Gastrochaenolites and Circolites were also present in fallen blocks.

The in situ borings affected the basement at several heights above the present-day sea level and were not randomly distributed along the gorges studied (Fig. 4). No borings were found in between the selected transects. At Section 1 of the Canuto de la Utrera, Gastrochaenolites, Circolites and Entobia successively appeared along the section, the first one leaving the most conspicuous and persistent traces (Fig. 4). The association of Gastrochaenolites, Circolites, and Ericichnus was present at $118 \mathrm{~m}$ in Section 2 (Fig. 4). Sections 3 and 4 showed only Gastrochaenolites, from 210 to $287 \mathrm{~m}$ of altitude (Fig. 4). Section 4 contained Gastrochaenolites, Entobia, and Caulostrepsis (Fig. 4). Possible traces of Circolites were also visible in Section 4, although their preservation precluded a precise identification.

In the Canuto Chico, only Gastrochaenolites and Ericichnus asgaardi were identified in the uppermost levels of the gorge (Fig. 4). Circolites were also sometimes present, but the preservation and the scarcity of potential specimens impeded a definitive identification.

\section{MICROFOSSIL ASSEMBLAGES}

\subsection{Planktonic foraminifera}

It bears mentioning that all samples studied are characterized by the presence of Globorotalia margaritae. At global scale, the first occurrence of $G$. margaritae is $5.59 \mathrm{Ma}$, latest Messinian (e.g. Kennett \& Srinivasan, 1983; Berggren et al., 1995; Wade et al., 2011). Nonetheless, according to the Mediterranean Pliocene foraminiferal biostratigraphy, $G$. margaritae is present in the first biozone MP11, although the first common occurrence of this species is $5.08 \mathrm{Ma}$, marking the base of the MP12 biozone (lower part of the early Pliocene) (Iaccarino et al., 1999; Lourens et al., 2004; Violanti, 2012). Therefore, all samples belong to the early Pliocene. However, the detailed analysis of the planktonic foraminiferal assemblages in each sample provides a more accurate age estimation.

From bottom to top, the stratigraphically lowest sample, HEDI-1, contains G. margaritae and abundant Sphaeroidinellopsis spp ( $S$. seminulina and $S$. kochi) (Figs $10 \mathrm{a}-10 \mathrm{c})$. Based on the dominance of this genus, this sample is assigned to the first biozone of the Mediterranean Pliocene, MP11 (5.33-5.08 Ma) (Violanti, 2012), which is characterized by an acme of Sphaeroidinellopsis.

The marls of the Canuto section (CAN-UTR-1 to CAN-UTR-3 samples) (Figs 1, 5) include Globorotalia margaritae, Globoturborotalia nepenthes, and Globorotalia cibaoensis (Figs 10d-e). The last occurrences of $G$. cibaoensis and $G$. nepenthes are $4.6 \mathrm{Ma}$ and 4.36 $\mathrm{Ma}$, respectively (Wade et al., 2011). Therefore, the deposition of the marls in the central part of the Canuto de la Utrera took place between 5.08 Ma (first common occurrence of $G$. margaritae) and 4.6 Ma (last occurrence of $G$. cibaoensis). It is worth mentioning that planktonic foraminifera in these three samples are noticeably smaller than the adult normal sizes.

In the stratigraphically highest sample, UTR-1 (Fig. 1), $G$. margaritae and $G$. nepenthes are present (Fig. 10f). This implies an early Pliocene age older than 4.36 Ma, the last occurrence of the latter species (Wade et al., 2011).

\subsection{Benthic foraminiferal assemblages}

Planktonic/benthic ratio ( $\mathrm{P} / \mathrm{B}$ ratio) is higher than $50 \%$ in all samples, except in HEDI-1 (46.3\%) (Table 1). The assemblages are dominated by epifaunal species $(>68.7 \%)$. All samples are characterized by Cibicides refulgens and Cibicides pachyderma, the two species accounting 


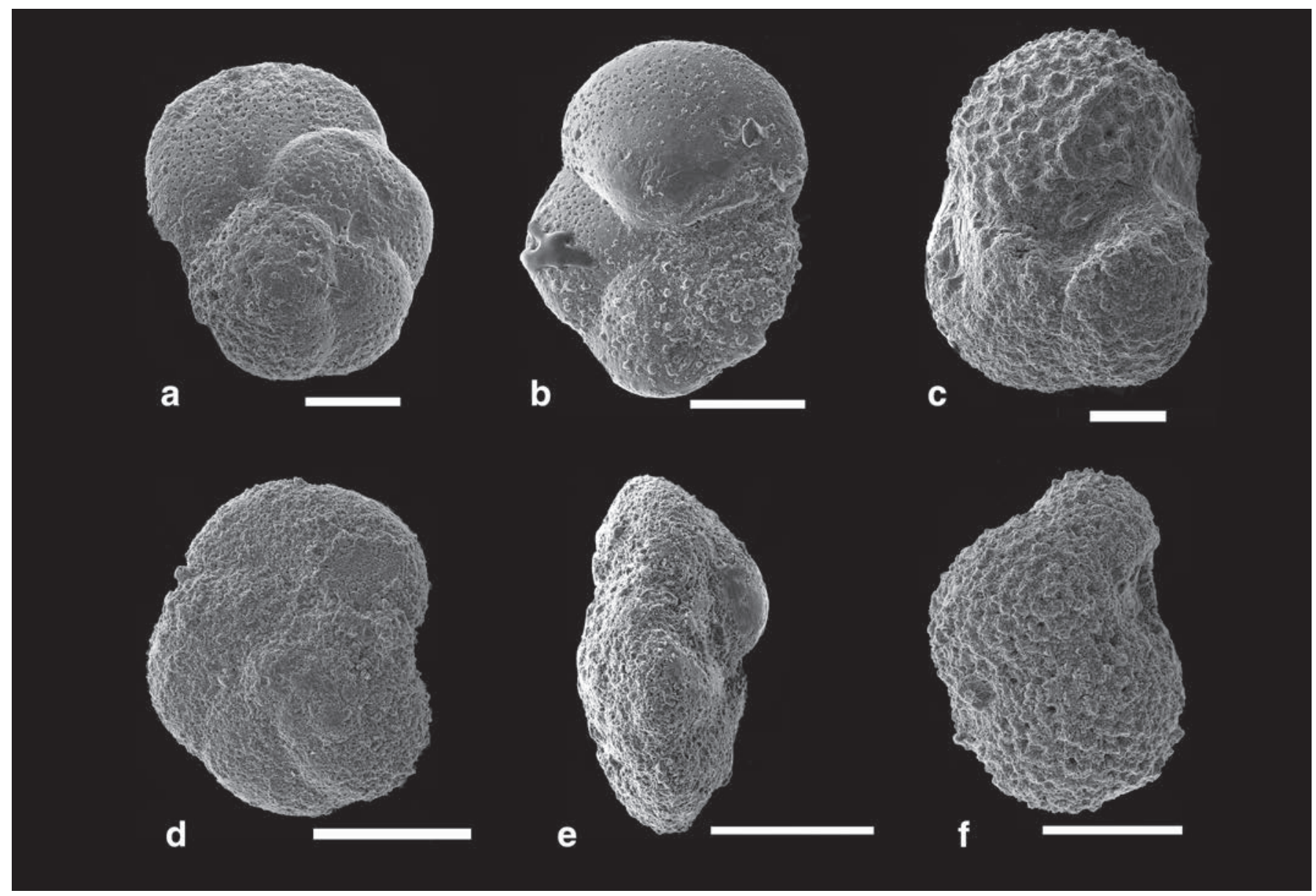

Figure 10. Planktonic foraminifera used for dating the deposits studied. a-b) Globorotalia margaritae in dorsal (a) and umbilical (b) views. HEDI-1. c) Sphaeroidinellopsis seminulina in umbilical side. HEDI-1. d-e) Globorotalia cibaoensis in dorsal (d) and lateral (e) views. CAN-UTR-1. f) Globoturborotalia cf. nepenthes in lateral view. UTR-1. Scale bars $=100 \mathrm{~mm}$.

for more than $25 \%$ of the total assemblage. Pullenia bulloides, Siphonina reticulata, Planulina ariminensis, and Anomalina flintii are also common species, except in the HEDI-1 sample. In the sample UTR-1, Elphidium crispum and Elphidium macellum also occurred as common species. All values of benthic foraminiferal assemblages are included in Table 1.

Table 1. Benthic foraminiferal assemblages of the studied samples indicating the percentage of each species (numbers in brackets). The planktonic/benthic ratio (P/B), as well as the percentages of infaunal and epifaunal species for each sample is also indicated.

\begin{tabular}{|c|c|c|c|c|}
\hline HEDI-1 & CAN-UTR-1 & CAN-UTR-2 & CAN-UTR-3 & UTR-1 \\
\hline Cibicides refulgens (29.7) & Cibicides pachyderma (15.3) & Cibicides pachyderma (13.3) & Cibicides refulgens (21.7) & Cibicides refulgens (19.0) \\
\hline Cibicides pachyderma (7.3) & Cibicides refulgens (10.3) & Cibicides refulgens (12.7) & Cibicides pachyderma (11.3) & Cibicides pachyderma (13.0) \\
\hline Bolivina spathulata $(6.0)$ & Bolivina spathulata (7.3) & Bolivina spathulata (6.7) & Bolivina spathulata $(6.7)$ & Elphidium crispum $(7.3)$ \\
\hline Neoeponides schreibersii (5.7) & Lobatula lobatula (5.7) & Lobatula lobatula (6.0) & Rosalina globularis (6.0) & Pullenia bulloides (4.7) \\
\hline Cibicides sp. (4.0) & Siphonina reticulata (5.7) & Trifarina bradyi (5.0) & Melonis barleeanus (5.0) & Uvigerina peregrina (4.7) \\
\hline Cibicidoides sp. (3.3) & Pullenia bulloides (4.7) & Rosalina globularis (4.3) & Lobatula lobatula (4.3) & Planulina ariminensis (4.3) \\
\hline \multirow[t]{5}{*}{ Lobatula lobatula (3.3) } & Anomalina flintii (4.3) & Melonis barleeanus (4.0) & Siphonina reticulata (4.3) & Cibicides sp. (3.0) \\
\hline & Cibicides sp. (3.7) & Globocassidulina subglobosa (3.3) & Siphonodosaria lepidula (4.0) & Elphidium macellum (3.0) \\
\hline & Siphonodosaria lepidula (3.3) & Pullenia bulloides (3.0) & & \\
\hline & Rosalina globularis (3.0) & Cibicides sp. (3.0) & & \\
\hline & & Spiroplectinella wrightii (3.0) & & \\
\hline P/B ratio: $46.3 \%$ & $\mathrm{P} / \mathrm{B}$ ratio: $75.7 \%$ & $\mathrm{P} / \mathrm{B}$ ratio: $75 \%$ & $\mathrm{P} / \mathrm{B}$ ratio: $68.3 \%$ & $\mathrm{P} / \mathrm{B}$ ratio: $51.7 \%$ \\
\hline Total epifauna: $79 \%$ & Total epifauna: $70.7 \%$ & Total epifauna: $68.7 \%$ & Total epifauna: $74.3 \%$ & Total epifauna: $73.7 \%$ \\
\hline Total infauna: $21 \%$ & Total infauna: $35.3 \%$ & Total infauna: $31.3 \%$ & Total infauna: $25.7 \%$ & Total infauna: $26.3 \%$ \\
\hline
\end{tabular}




\section{DISCUSSION}

\subsection{Palaeoenvironmental interpretation of the ichnoassemblages}

Bioerosion evidences a strong relation between the behaviour of the producers and the resulting traces based on their almost permanent emplacement. Ethologically, the ichnofossils identified belong to the domichnionpascichnion categories, and distinction among bioerosion due to the activity of endolithic (worms and bivalves), semi-endolithic (sessile sponges) and epilithic (mobile regular echinoids) organisms deserves comments. The presence of Entobia, Caulostrepsis, Circolites, Ericichnus, and Gastrochaenolites in the bored surfaces of the Mesozoic substrate of Sierra de la Utrera, as well as in the reworked blocks, allows this ichnoassemblage to be attributed to the archetypical Entobia Ichnofacies in hard substrates. This ichnofacies has been classically interpreted as an indicator of shallow- to very-shallowwater settings with a low or null sedimentation (Bromley \& Asgaard, 1993; Martinell \& Domènech, 1995; Aguirre \& Jiménez, 1997; Gibert et al., 1998, 2012; Silva et al., 1999; Domènech et al., 2001; Santos et al., 2008a, 2011a, 2011b, 2012a, 2012b; Cachão et al., 2009; Johnson et al., 2011; Aguirre et al., 2014, among many others).

However, Bassi et al. $(2011,2012)$ have recently described similar ichnofossil assemblages in macroids collected at 60-100 m water depth, from SW Kikaijima ( $\mathrm{N}$ of Ryukyu Islands, S Japan). The authors concluded that their findings challenge the paradigm of the Entobia-Gastrochaenolithes-Trypanites-Meandropolydora ichnoassemblage as a palaeobathymetric proxy. Alternatively, Bassi et al. $(2011,2012)$ stated that this ichnoassemblage is more reliable as an indicator of frequent turbulence and low sedimentation rates, rather than a water-depth indicator.

Although the results of Bassi et al. $(2011,2012)$ are challenging, numerous quantitative studies and qualitative observations show a decrease in boring intensity and rates with depth both in the tropics and in high-latitude settings (see summary in Wisshak, 2006). In general, macroborers increase in shallow waters as well as with the time of exposure of the substrate (e.g. Tribollet \& Golubic, 2005; Wisshak, 2006). In the case of polychaetes, they are important macroborers from 1 to $7 \mathrm{~m}$ water depth and Caulostrepsis isp. significantly decreases below its highest abundance at $15-30 \mathrm{~m}$ in cold-temperate areas (Wisshak, 2006).

In addition, bioeroding activity by echinoids is constrained to high-energy very shallow waters worldwide, close to the low-tide line (see a review in Asgaard \& Bromley, 2008). In the Mediterranean, Martinell (1981) described dense concentrations of Paracentrotus lividus within their characteristic cup-shaped traces, Circolites, in rockgrounds of different lithologies. The same applies for the grooves formed by echinoids, Ericichnus (Asgaard $\&$ Bromley, 2008). Therefore, the significant presence of Circolites kotoucensis and Ericichnus asgaardi both in the Canuto de la Utrera and in the Canuto Chico restricts the palaeodepth of the identified boring associations to very shallow waters. Moreover, based on the observations of Bassi et al. $(2011,2012)$ the ichnoassemblages described point to a low or null sedimentation rate as well as high water turbulence, inherent to these shallow-water settings.

Regarding the sediment deposited adjacent to the Sierra de la Utrera, benthic foraminiferal assemblages account for the palaeoenvironmental settings. The high abundance of epifaunal species indicates well-oxygenated and oligotrophic conditions (Jorissen et al., 1995). In terms of palaeobathymetry, the samples are dominated by Cibicides refulgens and Cibicides pachyderma, which live from the outer shelf to the upper slope (van Morkhoven et al., 1986; Barbieri \& Ori, 2000; Schönfeld, 2002; Murray, 2006; Villanueva-Guimerans \& Canudo 2008; Pérez-Asensio \& Aguirre, 2010; Pérez-Asensio et al., 2014; Aguirre et al., 2015). Samples CAN-UTR-1 to CAN-UTR-3 also contain taxa common in slope settings, including Siphonina reticulata, Pullenia bulloides and Anomalina flintii (Berggren \& Haq, 1976; Berggren et al., 1976; Hayward et al., 2003; Pérez-Asensio et al., 2012). Finally, P/B ratios higher than $40 \%$ are also compatible with these settings (Murray, 1991, 2006).

The presence of very steep rocky shores with nearly vertical submarine cliffs accounts for these relatively deepwater conditions prevailing very close to the palaeocoast, in the vicinity of the Sierra de la Utrera, as well as in the centre of the Canuto de la Utrera. In this context, the presence of bored surfaces in very shallow waters is compatible with outer-shelf or upper-slope deposits adjacent to them.

\subsection{Sea-level change and palaeogeographic evolution}

As commented above, Pliocene marine deposits of the Manilva Basin onlap the Mesozoic basement of the Sierra de la Utrera. This stratigraphic architecture attests for an early Pliocene relative sea-level rise. The biostratigraphic data indicate that the sea-level rise coincides with the early Pliocene transgression detected globally (Haq et al., 1987; Snedden \& Liu, 2010). At maximum, the inundation of the relief took place in a time interval of about $1 \mathrm{Ma}$, from 5.33 at HEDI-1 to 4.36 at UTR-1.

Boring organisms including sponges, worms, bivalves, and regular echinoids, producing Entobia, Caulostrepsis, Gastrochaenolites, and Circolites plus Ericichnus traces, respectively, colonized the Betic basement. The in situ 
A

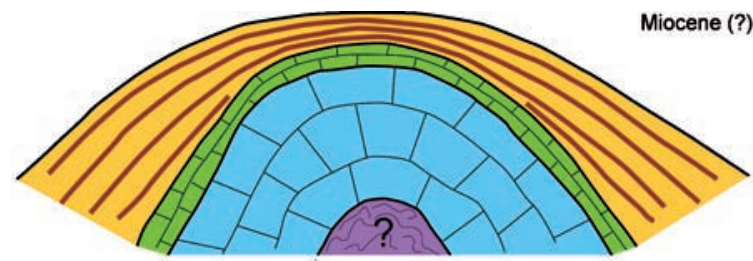

B
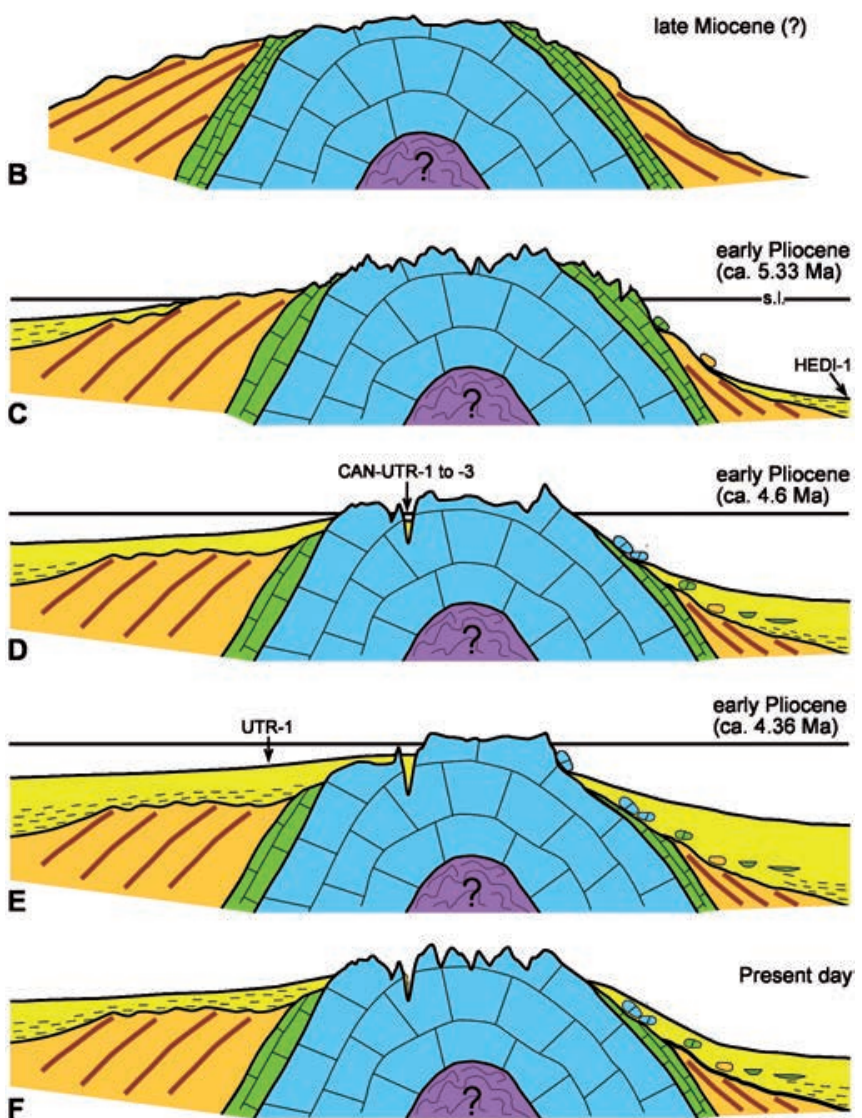

$\square$ limestones (Lower Cretaceous)
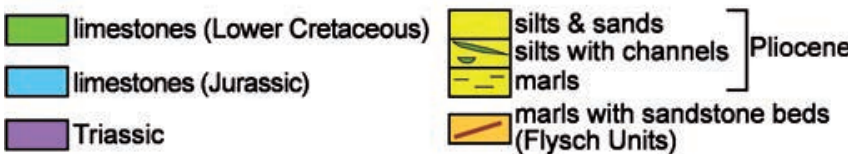

Figure 11. Sketches showing the inferred evolution of the Sierra de la Utrera and the variations in sea level (s.l.) during the Pliocene deduced from the ichnoassemblages and foraminiferal assemblages. Labels in drawings (c), (d), and (e) refer to the position of the samples analysed at the time of their formation based on the planktonic foraminiferal assemblages. Sketches not to scale. (See details in the text).

borings, as well as those present in the fallen boulders, indicate the approximate position of the coastline at different times of the deepening trend. However, the succession of the boring activity is hard to determine from the field data alone since they appear at different heights above the present-day sea level, from 96 to 287 $\mathrm{m}$, but overprinting among them is unclear. This prevents an assessment of a historical succession of boring activity and, consequently, the establishment of the sequence of sea level and palaeogeographic evolution of the Manilva Basin during the early Pliocene transgression.

Microfossil assemblages collected from the Pliocene sediments surrounding the Sierra de la Utrera supplement this lack of information. They add evidence to infer palaeogeographic and sea-level changes in the Manilva Basin based on two main aspects: 1) planktonic foraminifera provide a reliable time frame for the sea-level change that led to the formation of bored surfaces at different heights; and, 2) benthic foraminifera allow to contextualise the palaeoenvironmental conditions prevailing in the Manilva Basin, which are approximately coeval with the bioerosion of the substrate (oligotrophic, well-ventilated deep-water conditions, as stated above). Therefore, consolidation of all the information is needed to reliably reconstruct changes in the Manilva Basin during the early Pliocene sea-level rise.

The Sierra de la Utrera anticline formed during the Miocene (Durand-Delga, 2006; Balanyá et al., 2012; González-Castillo et al., 2015) (Fig. 11a) as the result of the westward movement of the Betic mountain range (González-Castillo et al., 2015). Later, this relief continued to be tectonically stable, given that the Pliocene deposits are not significantly distorted or folded. They are only slightly tilted $\left(<5^{\circ}\right)$ dipping to the SSE due to postPliocene uplifting of the Sierra de la Utrera (DurandDelga, 2006). Due to this tectonic stability, the spatial distribution of the bored surfaces found at different heights above present-day sea level allows the reconstruction of the position of the palaeocoast at different times during the deepening trend.

The Sierra de la Utrera remained emerged up to the earliest Pliocene, when marine deposition started in the Manilva Basin (Figs 11a-c). During this time interval, the marls and sandstones of the Flysch Units, followed by the Early Cretaceous marly limestones and then the Jurassic limestones, were successively eroded away. Blocks and boulders of the bored substrates, successively older as Pliocene transgression advanced, were deposited at the toe of submarine cliffs (Figs 11c-e). The first big boulders embedded in the Pliocene sediments are sandstones of the Flysch Units (Fig. 7d). Higher up into the section, big blocks of Early Cretaceous limestones and marly limestones are present (Fig. 7e). Finally, in the upper half part of the section, bored boulders are Jurassic limestones (Fig. 7f). This succession is recorded in the Álamos section, on the eastern side of the Sierra de la Utrera (Fig. 5), but not on the western side. This spatial difference suggests that the eastern side of the relief was most likely characterized by the existence of palaeocliffs providing boulders of different lithologies as the substrate became eroded, while the western palaeocoast was presumably less rough (Figs 11c-d).

Planktonic foraminifera of sample HEDI-1 indicates an early Pliocene age (MPl1 biozone) for the first marine deposits recorded in the Manilva Basin (Fig. 11c). 
During this initial flooding, benthic foraminifera suggest an environment near the outer-middle shelf transition (Fig. 11c). It is uncertain that the deposits of HEDI-1 were coeval with the boring activity in the adjacent palaeocliffs. Nonetheless, the successive presence of fallen blocks included in the Pliocene sediments suggests that the bioeroder communities developed during this time frame.

Following the initial marine inundation of the Manilva Basin, Pliocene sediments onlap the Mesozoic relief of Sierra de la Utrera, testifying to the continuous sea-level rise (Figs 11d-e). Bored surfaces located at progressively higher positions in the Sierra de la Utrera (Fig. 4) account for this deepening. Planktonic foraminiferal assemblages provide the age estimation for the palaeocoast position (Figs 11d-e).

As the sea level rose, the karstification of the Mesozoic basement continued. This led to the eventual marine invasion of karstified surfaces and to deposition of marls with abundant marine fauna in the central part of the Canuto de la Utrera (Figs 11c-e). The Jurassic limestones covered by these marls also show bivalve borings (Gastrochaenolites) confirming the marine inundation. Planktonic foraminifera found in CAN-UTR-1 to CAN-UTR-3 samples are considerably small. Dwarfed microfauna are generally attributed to stressful conditions (e.g. Van de Poel, 1991, 1992; Abramovich \& Keller, 2003; Corbí et al., 2016). In the study case, the limited extension of the marls in Canuto de la Utrera suggests that deposition could have taken place in deep cracks associated with karstification and/or tectonic (joints and/or faults). This particular sciaphilous setting would account for the stressful conditions limiting the growth of planktonic foraminifera. In addition, these palaeoenvironmental conditions are consistent with the deposition of marls and the relatively deep-water benthic foraminiferal assemblages found in the Canuto section.

The highest bored surfaces are in Canuto Chico and in Section 4, at $283 \mathrm{~m} 287 \mathrm{~m}$ above present-day sea level, respectively (Fig. 4). This is nearly $40 \mathrm{~m}$ higher than the topographically highest sample UTR-1 (250 m) (Fig. 1b). Benthic foraminiferal assemblage of this sample indicates outer-shelf conditions. In the recent platform of the nearby Mediterranean, the outer platform ranges from $\sim 70$ to 100 $\mathrm{m}$. The palaeogeographic restriction of the Manilva Basin (Fig. 6) suggests that similar palaeobathymetric conditions were probably established at shallower settings during the early Pliocene. Thus, an estimation of about $50 \mathrm{~m}$ water depth for the deposition of sample UTR-1 is reasonable. The presence of abundant inner-shelf benthic foraminifera in UTR-1, such as Elphidium crispum and E. macellum that live between 0 and $50 \mathrm{~m}$ depth (Murray, 1991, 2006), agrees with the shallower position inferred above. This means that in the vertical of this sample the sea-water level was ca. $50 \mathrm{~m}$ above the sea bottom. This is consistent with the palaeocoast located approximately at the same level when the highest boring palaeocommunities of Canuto Chico and Section 4 were active. Given the virtual absence of Pliocene tectonics in the area, the time estimate for the boring activity in Canuto Chico and in the highest part of Section 4 can be taken as that determined in sample UTR1, i.e. about $4.36 \mathrm{Ma}$ (Fig. 11e).

It is not clear whether the whole sierra was completely submerged during the early Pliocene flooding or some emerged parts remained as small islands (Fig. 11e). The highest point of Sierra de la Utrera, $354 \mathrm{~m}$, is nearly 65 $\mathrm{m}$ higher than the highest bored surfaces at Canuto Chico and Section 4. As inferred above, the boring activity in these surfaces took place at $\sim 4.36 \mathrm{Ma}$. This date coincides with the maximum flooding reached during the Zanclean, which characterizes the global Neogene sea-level cycle Za 1 (Snedden \& Liu, 2010), which, in turn, took place during a relatively warm period ( 4.5-4.3 Ma) (Hansen et al., 2013; Rohling et al., 2014). It is presumed that the highest bored surfaces in the Sierra de la Utrera were most likely formed during the early Pliocene maximum flooding and, therefore, parts of the Mesozoic substrate emerged, forming small islands (Fig. 11e).

The palaeogeographic evolution depicted above contrasts with that proposed by Guerra-Merchán et al. (2014). These authors considered that the Casares-Manilva area remained emerged during most of the early Pliocene and that the Manilva Basin was inundated at the end of the early Pliocene, from 4.63 to about 4.28 Ma. Our data clearly indicate that the Pliocene infill in the Manilva Basin started earlier, at the base of the early Pliocene.

\section{CONCLUSIONS}

The Penibetic relief of Sierra de la Utrera, in the Manilva Basin (Málaga, SW Spain), shows bored surfaces distributed from $96 \mathrm{~m}$ to $287 \mathrm{~m}$ above present-day sea level. The traces are found along the Canuto de la Utrera and Canuto Chico, two gorges that cut the relief in its central-southern and northern parts, respectively.

The boring activity is recorded in different lithologies from the basement: 1) turbiditic sandstones of the Flysch Units of the Betic Cordillera, 2) Early Cretaceous marly limestones and limestones, and 3) Jurassic limestones. Pliocene marine deposits onlap the basement, thus fossilizing the bored surfaces. In addition to the in situ borings affecting the substrate, boulders and large blocks derived from the basement and embedded in the Pliocene deposits also show borings. These bored boulders occur exclusively in the eastern side of the Sierra de la Utrera, indicating the existence of palaeocliffs.

The observed ichnoassemblages are characterized mostly by bivalve borings attributed to Gastrochaenolites 
ispp, followed by traces of sponges (Entobia ispp), worm borings (Caulostrepsis ispp), and echinoid traces (Circolites kotoucensis and Ericichnus asgaardi). Caulostrepsis is found only in the reworked boulders embedded in the Pliocene deposits. These trace fossils correspond to the archetypical Entobia Ichnofacies of rocky shores. They were formed in very shallow waters, close to the sea level, with high hydraulic energy and a low or null sedimentation rate.

The vertical distribution of bored surfaces and the onlap geometry of the Pliocene deposits suggest a progressive sea-level rise. Planktonic foraminiferal assemblages of the Pliocene deposits adjacent to the Sierra de la Utrera indicate that the sea level rose during the early Pliocene, Zanclean (MP11 and MPl2 biozones), from 5.33 Ma to $4.36 \mathrm{Ma}$ at maximum age range. Benthic foraminiferal assemblages suggest that oligotrophic, well-oxygenated, relatively deep-water conditions prevailed surrounding the relief.

\section{ACKNOWLEDGEMENTS}

The authors acknowledge the thorough reviews of the manuscript by Drs Wisshak and Mikulas. Their comments and suggestions have substantially improved the quality of the paper. The English text was corrected by David Nesbitt. This paper has been partially supported by the Research Projects CGL2013-47236-P and CGL2015-66835-P of the Ministerio de Ciencia e Innovación of Spain, the Research Groups RNM-190 and RNM276 of the Junta de Andalucía and the Fondo Europeo de Desarrollo Regional (FEDER).

\section{REFERENCES}

Abramovich, S. \& Keller, G. 2003. Planktonic foraminiferal response to the latest Maastrichtian abrupt warm event: a case study from South Atlantic DSDP Site 525A. Marine Micropaleontology, 48, 225-249; doi: 10.1016/S03778398(03)00021-5.

Aguirre, J. 2000. Evolución paleombiental y análisis secuencial de los depósitos pliocenos de Almayate (Málaga, sur de España). Revista de la Sociedad Geológica de España, 13, 431-443.

Aguirre, J. \& Jiménez, A.P. 1997. Census assemblages in hard-bottom coastal communities: a case study from the Plio-Pleistocene Mediterranean. Palaios, 12, 598-608; doi: $10.2307 / 3515415$.

Aguirre, J., Cachão, M., Domènech, R., Lozano-Francisco, M.C., Martinell, J., Mayoral, E., Santos, A., Vera-Peláez, J.L. \& Silva, C.M. da 2005. Integrated biochronology of the Pliocene deposits of the Estepona Basin (Málaga, S
Spain). Palaeobiogeographic and palaeoceanographic implications. Revista Española de Paleontología, 20, 225-244.

Aguirre, J., Belaústegui, Z., Domènech, R., Gibert, J.M. de \& Martinell, J. 2014. Snapshot of a lower Pliocene Dendropoma reef from Sant Onofre (Baix Ebre Basin, Tarragona, NE Spain). Palaoegeography, Palaeoclimatology, Palaeoecology, 395, 9-20; doi: 10.1016/j.palaeo.2013.12.011.

Aguirre, J., Braga, J.C., Martín, J.M., Puga-Bernabéu, Á., Pérez-Asensio, J.N., Sánchez-Almazo, I.M., Génio, L. 2015. An enigmatic kilometer-scale concentration of small mytilids (Late Miocene, Guadalquivir Basin, S Spain). Palaeogeography, Palaeoclimatology, Palaeoecology, 436, 199-213; doi: 10.1016/j.palaeo.2015.07.015.

Asgaard, U. \& Bromley, R.G. 2008. Echinometrid sea urchins, their trophic styles and corresponding bioerosion. In: Current Developments in Bioerosion (eds Wisshak, M. \& Tapanila, L.). Springer-Verlag, Berlin. 279-303.

Balanyá, J.C., Crespo-Blanc, A., Diaz-Azpiroz, M., Expósito, I., Torcal, F., Pérez-Peña, V. \& Booth-Rea, G. 2012. Arcparallel vs back-arc extension in the Western Gibraltar arc: is the Gibraltar forearc still active? Geologica Acta, 10, 249-263.

Barbieri, R. \& Ori, G.G. 2000. Neogene palaeoenvironmental evolution in the Atlantic side of the Rifian Corridor (Morocco). Palaeogeography, Palaeoclimatology, Palaeoecology, 163, 1-31; doi: 10.1016/S00310182(00)00100-0.

Bassi, D., Humblet M. \& Iryu, Y. 2011. Recent ichnocoenosis in deep water macroids, Ryukyu Islands, Japan. Palaios, 26, 232-238; doi: 10.2110/palo.2010.p10-093r.

Bassi, D., Iryu, Y., Humblet, M., Matsuda, H., Machiyama, H., Sasaki, K., Matsuda, S., Arai, K. \& Inoue, T. 2012. Recent macroids on the Kikai-jima shelf, Central Ryukyu Islands, Japan. Sedimentology, 59, 2024-2041; doi: 10.1111/j.13653091.2012.01333.x.

Belaústegui, Z., Muñiz, F., Nebelsick, J.H., Domènech, R. \& Martinell, J. in press. Echinoderm ichnology: bioturbation, bioerosion and related processes. Journal of Paleontology. Echinoderm Special Issue. doi: 10.1017/jpa.2016.146.

Berggren, W.A. \& Haq, B.U. 1976. The Andalusian Stage (Late Miocene): biostratigraphy, biochronology and palaeoecology. Palaeogeography, Palaeoclimatology, Palaeoecology, 20, 67-129; doi: 10.1016/00310182(76)90026-2.

Berggren, W.A., Benson, R.H., Haq, B.U., Riedel, W.R., Sanfilippo, A., Schrader, H.J. \& Tjalsma, R.C. 1976. The El Cuervo Section (Andalusia, Spain): micropaleontologic anatomy of an early Late Miocene lower bathyal deposit. Marine Micropaleontology, 1, 195-247; doi: 10.1016/0377-8398(76)90009-8.

Berggren, W.A., Hilgen, F.J., Langereis, C.G., Kent, D.V., Obradovich, J.D., Raffi, I., Raymo, M.E. \& Shackleton, N.J. 1995. Late Neogene chronology: New perspectives in high resolution stratigraphy. Geological Society of America Bulletin, 107, 1272-1287; doi: 10.1130/0016-7606(1995)107<1272:LNCNPI>2.3.CO;2. 
Bromley, R.G. \& Asgaard, U. 1993. Endolithic community replacement on a Pliocene rocky coast. Ichnos, 2, 93-116; doi: 10.1080/10420949309380081.

Cachão, M., Silva, C.M. da, Santos, A., Domènech, R., Martinell, J. \& Mayoral, E. 2009. The bioeroded megasurface of Oura (Algarve, south Portugal): Implications for the Neogene stratigraphy and tectonic evolution of southwest Iberia. Facies, 55, 213-225; doi: 10.1007/s10347-008-0172-2.

Corbí, H., Soria, J.M., Lancis, C., Giannetti, A., TentManclús, J.E. \& Dinarès-Turell, J. 2016. Sedimentological and paleoenvironmental scenario before, during, and after the Messinian Salinity Crisis: The San Miguel de Salinas composite section (western Mediterranean). Marine Geology, 379, 246-266; doi: 10.1016/j. margeo.2016.05.017.

Domènech, R., Gibert, J.M. de \& Martinell, J. 2001. Ichnological features of a marine transgression: Middle Miocene rocky-shores of Tarragona, Spain. Geobios, 34, 99-107; doi: 10.1016/S0016-6995(01)80051-6.

Domènech, R., Juilleret, J. \& Martinell, J. 2014. Delimitando la costa burdigaliense en el Jura francés mediante la bioerosión sobre acantilados. Fundamental!, 24, 83-86.

Durand-Delga, M., 2006. Geological adventures and misadventures of the Gibraltar Arc. Zeitschrift der Deutschen Gesellschaft für Geowissenschaften, 157, 687-716; doi: 10.1127/1860-1804/2006/0157-0687.

Gibert, J.M. de, Martinell, J. \& Domènech, R. 1998. Entobia ichnofacies in fossil rocky shores, Lower Pliocene, northwestern Mediterranean. Palaios, 13, 476-487; doi: 10.1043/0883-1351(1998)013<0476:EIIFRS>2.0.CO;2.

Gibert, J.M. de, Domènech, R. \& Martinell, J. 2012. Rocky shorelines. In: Trace Fossils as Indicators of Sedimentary Environments (eds Knaust, D. \& Bromley, R.G.). Developments in Sedimentology, 64, 441-462.

González-Castillo, L., Galindo-Zaldivar, J., de Lacy, M.C., Borque, M.J., Martínez-Moreno, F.J., García-Armenteros, J.A. \& Gil, A.J. 2015. Active rollback in the Gibraltar Arc: Evidences from GGSP data in the western Betic Cordillera. Tectonophysics, 663, 310-321.

Gonazález-Donoso, J.M., Linares, D., Martín-Algarra, A., Rebollo, M., Serrano, F. \& Vera, J.A. 1983. Discontinuidades estratigráficas durante el Cretácico en el Penibético. Estudios Geológicos, 29, 71-116.

Guerra-Merchán, A., Serrano, F., Hlila, R., El Kadiri, K., Sanz de Galdeano, C. \& Garcés, M. 2014. Tectono-sedimentary evolution of the peripheral basins of the Alboran Sea in the arc of Gibraltar during the latest Messinian-Pliocene. Journal of Geodynamics, 77, 158-170; doi: 10.1016/j. jog.2013.12.003.

Haq, B.V., Hardenbol, J. \& Vail, P.R. 1987. Chronology of fluctuating sea levels since the Triassic. Science, 235, 1156-1167; doi: 10.1126/science.235.4793.1156.

Hayward, B.W., Grenfell, H.R., Sabaa, A. \& Hayward, J.J. 2003. Recent benthic foraminifera from offshore Taranaki, New Zealand. New Zealand Journal of Geology and Geophysics, 46, 489-518; doi: 10.1080/00288306.2003.9515024.
Hansen, J., Sato, M., Russell, G. \& Kharecha, P. 2013. Climate sensitivity, sea level and atmospheric carbon dioxide. Philosophical Transactions of the Royal Society A, 371: 20120294; doi: 10.1098/rsta.2012.0294.

Iaccarino, S.M., Cita, M.B., Gaboardi, S. \& Gruppini, G.M. 1999. High-resolution biostratigraphy at the Miocene/ Pliocene boundary in Holes 974B and 975B, western Mediterranean. Proceedings of the Ocean Drilling Program, Scientific Results (eds Zahn, R., Comas, M.C. \& Klaus, A.), 161, 197-221.

Johnson, M.E. 1988a. Why are ancient rocky shores so uncommon? Journal of Geology, 96, 469-480.

Johnson, M.E. 1988b. Hunting for ancient rocky shores. Journal of Geological Education, 36, 147-154.

Johnson, M.E. \& Baarli, B.G. 1999. Diversification of rocky shore biotas through geologic time. Geobios, 32, 257-273; doi: 10.1016/S0016-6995(99)80040-0.

Johnson, M.E. \& Baarli, B.G. 2012. Development of intertidal biotas through Phanerozoic time. In: Earth and Life. Global Biodiversity, Extinction Intervals and Biogeographic Perturbations Through Time (ed. Talent, J.A.). Springer Science. 63-128.

Johnson, M.E., Baarli, B.G., Santos, A. \& Mayoral, E. 2011. Ichnofacies and microbial build-ups on Late Miocene rocky shores from Menorca (Balearic Islands), Spain. Facies, 57, 255-265; doi: 10.1007/s10347-010-0240-2.

Jorissen, F.J., de Stigter, H.C. \& Widmark, J.G.V. 1995. A conceptual model explaining benthic foraminiferal microhabitats. Marine Micropaleontology, 26, 3-15; doi: 10.1016/0377-8398(95)00047-X.

Kennett J.P. \& Srinivasan M.S. 1983. Neogene Planktonic Foraminifera - A Phylogenetic Atlas. Hutchinson Ross Publishing Company, Stroudsburg, Pennsylvania, U.S.A. $265 \mathrm{pp}$,

Lourens, L.J., Hilgen, F.J., Shackleton, N.J., Laskar, J. \& Wilson, D.S. 2004. The Neogene Period. In: A Geologic Time Scale 2004 (eds Gradstein, F.M., Ogg, J.G. \& Smith, A.G.). Cambridge University Press, Cambridge, 409-440.

Martín-Algarra, A. 1987. Evolución geológica alpina del contacto entre las Zonas Internas y las Zonas Externas de la Cordillera Bética. Ph.D. Thesis, University of Granda. 2 Vols, $1171 \mathrm{pp}$.

Martinell, J. 1981. Actividad erosiva de Paracentrotus lividus (Lmk.) (Echinodermata, Echinoidea) en el litoral gerundense. Oecología Acuática, 5, 219-225.

Martinell, J. \& Domènech, R. 1986. Actividad bioerosiva en el Plioceno del Empordà (Catalunya). Paleontologia $i$ Evolució, 20, 247-251.

Martinell, J. \& Domènech, R. 1995. Bioerosive structures on the Pliocene rocky shores of Catalonia (Spain). Revista Española de Paleontología, 10, 37-44.

Martinell, J., Domènech, R., Mayoral, E. \& Santos, A. 2008. Geodynamic and paleogeographic implications of a Pliocene bioerosive episode in El Canuto de la Utrera (Casares, Betic Cordillera, S Spain). $6^{\text {th }}$ International Bioerosion Workshop, Salt Lake City, Utah (USA).

Murray, J.W. 1991. Ecology and Palaeoecology of Benthic Foraminifera. Longman Scientific \& Technical, UK. 
Murray, J.W. 2006. Ecology and Applications of Benthic Foraminifera. Cambridge University Press, Cambridge.

Pérez-Asensio, J.N. \& Aguirre, J. 2010. Benthic foraminiferal assemblages in temperate coral-bearing deposits from the Late Pliocene. Journal of Foraminiferal Research, 40, 61-78; doi: 10.2113/gsjfr.40.1.61.

Pérez-Asensio, J.N., Aguirre, J., Schmiedl, G. \& Civis, J. 2012. Messinian paleoenvironmental evolution in the lower Guadalquivir Basin (SW Spain) based on benthic foraminifera. Palaeogeography, Palaeoclimatology, Palaeoecology, 326-328, 135-151; doi: 10.1016/j. palaeo.2012.02.014.

Pérez-Asensio, J.N., Aguirre, J., Schmiedl, G. \& Civis, J. 2014. Messinian productivity changes in the northeastern Atlantic and their relationship to the closure of the Atlantic-Mediterranean gateway: implications for Neogene palaeoclimate and palaeoceanography. Journal of the Geological Society, London, 171, 389-400; doi: 10.1144/jgs2013-032.

Rodríguez-Tovar, F., Uchman, A. \& Puga-Bernabéu, A. 2015. Borings in gneiss boulders in the Miocene (Upper Tortonian) of the Sorbas Basin, SE Spain. Geological Magazine, 152, 287-297; doi: https://doi.org/10.1017/ S0016756814000302.

Rohling, E.J., Foster, G.L., Grant, K.M., Marino, G., Roberts, A.P., Tamisies, M.E. \& Williams, F. 2014. Sea-level and deep-sea-temperature variability over the past 5.3 million years. Nature, 508, 477-482; doi: 10.1038/nature13230.

Santos, A. \& Mayoral, E. 2016. Two remarkable examples of Portuguese Neogene bioeroded rocky shores: new data and synthesis. Comunicações Geológicas, 103 (Especial), 121-130.

Santos, A., Mayoral, E. \& Bromley, R.G. 2011a. Bioerosive structures from Miocene marine mobile-substrate communities in Southern Spain, and description of a new sponge boring. Palaeontology, 54, 535-545; doi: 10.1111/j.1475-4983.2011.01040.x.

Santos, A., Mayoral, E., Dumont, C.P., Silva, C.M. da, Ávila, S.P., Baarli, B.G., Cachão, M., Johnson, M.E. \& Ramalho, R.S. 2015. Role of environmental change in rock-boring echinoid trace fossils. Palaeogeography, Palaeoclimatology, Palaeoecology, 432, 1-14; doi: 10.1016/j.palaeo.2015.04.029.

Santos, A., Mayoral, E., Johnson, M.E., Baarli, B.G., Cachão, M., Silva, C.M. da \& Ledesma-Vázquez, J. 2012a. Extreme habitat adaptation by boring bivalves on volcanically active paleoshores from North Atlantic Macaronesia. Facies, 58, 325-338; doi: 10.1007/s10347011-0283-z.

Santos, A., Mayoral, E., Silva, C.M. da, Cachão, M. \& Kullberg, J.C. 2010. Trypanites ichnofacies: Palaeoenvironmental and tectonic implications. A case study from the Miocene disconformity at Foz da Fonte (Lower Tagus Basin, Portugal). Palaoegeography, Palaeoclimatology, Palaeoecology, 292, 35-43; doi: 10.1016/j.palaeo.2010.03.023.

Santos, A., Mayoral, E., Silva C.M. da, Cachão, C., Domènech, R. \& Martinell, J. 2008a. Trace fossil assemblages on Miocene rocky shores of southern Iberia. In: Current Developments in Bioerosion (eds Wisshak, M. \& Tapanila, L.). Springer Verlag, 431-450.

Santos, A., Mayoral, E., Domènech, R., Martinell, J. \& Aguirre, J. 2008b. Bioerosional evidence of a marine transgression (Early Pliocene, South Spain). The Second International Congress on Ichnology, ICHNIA 2008. Abstract Book, Polish Geological Institute, Warszawa, 112.

Santos, A., Mayoral, E., Silva, C.M. da, Cachão, M., Johnson, M.E. \& Baarli, B.G. 2011b. Miocene intertidal zonation on a volcanically active shoreline: Porto Santo in the Madeira Archipelago, Portugal. Lethaia, 44, 26-42; doi: 10.1111/j.1502-3931.2010.00222.x.

Santos, A., Mayoral, E., Johnson, M.E., Baarli, B.G., Silva, C.M. da, Cachão, M. \& Ledesma-Vázquez, J. 2012 b. Basalt mounds and adjacent depressions attract contrasting biofacies on a volcanically active Middle Miocene coastline (Porto Santo, Madeira Archipelago, Portugal). Facies, 58, 573-585; doi: 10.1007/s10347-012-0301-9.

Sendra, G., Marín, A.I., Mundarra, M. \& Andreo, B. 2013. Caracterización hidrogeológica preliminar, evaluación de recursos hídricos y vulnerabilidad a la contaminación del acuífero kárstico de la Sierra de la Utrera (provincia de Málaga). Geotemas.

Schönfeld, J. 2002. Recent benthic foraminiferal assemblages in deep high-energy environments from the Gulf of Cadiz (Spain). Marine Micropaleontology, 44, 141-162; doi: 10.1016/S0377-8398(01)00039-1.

Silva, C.M. da, Cãchao, M., Martinell, J. \& Domènech, R. 1995. Estruturas Bioerosivas como indicadores de Paleolitorais rochosos. O exemplo do Miocenico da Foz da Fonte (Sesimbra, Portugal). Dados preliminares. Memórias do Museu e Laboratório Mineralógico e Geoloógico da FCUP, 4, 133-137.

Silva, C.M. da, Cachão, M., Martinell, J. \& Domènech, R. 1999. Bioerosional evidence of rocky palaeoshores in the Neogene of Portugal: Environmental and stratigraphical significance. Bulletin of the Geological Society of Denmark, 45, 156-160.

Snedden, J.W. \& Liu, C. 2010. A compilation of Phanerozoic sea-level change, coastal onlaps and recommended sequence designations. Available at http://www. searchanddiscovery.com/documents/2010/40594snedden/ ndx_snedden.pdf of the American Association of Petroleum Geologists.

Tapanila, L. 2008. The endolithic guild: an ecological framework for residential cavities in hard substrates. In: Current Developments in Bioerosion (eds Wisshak, M. \& Tapanila, L.). Erlangen Earth Conference Series, Springer, 3-20.

Taylor, P.D. \& Wilson, M.A. 2003. Palaeoecology and evolution of marine hard substrate communities. EarthScience Reviews, 62, 1-103; doi: 10.1016/S00128252(02)00131-9.

Tribollet, A. \& Golubic, S. 2005. Cross-shelf differences in the pattern and pace of bioerosion of experimental carbonate substrates exposed for 3 years on the northern 
Great Barrier Reef, Australia. Coral Reefs, 24, 422-434; doi: 10.1007/s00338-005-0003-7.

Van de Poel, H.M. 1991. Messinian stratigraphy of the Nijar Basin (S.E. Spain) and the origin of its gypsum-ghost limestones. Geologie en Mijnbouw, 70, 215-234.

Van de Poel, H.M. 1992. Foraminiferal biostratigraphy and palaeoenvironments of th Miocene-Pliocene CarbonerasNijar Basin (SE Spain). Scripta Geologica, 102, 1-32.

Van Morkhoven, F.P.C.M., Berggren, W.A. \& Edwards, A.S. 1986. Cenozoic cosmopolitan deep-water benthic foraminifera. Bulletin des Centres de Recherches Exploration-Production Elf-Aquitaine, Mémoire, 11. Pau.

Villanueva-Guimerans, P. \& Canudo, I. 2008. Assemblages of recent benthic foraminifera from the northeastern Gulf of Cádiz. Geogaceta, 44, 139-142.

Violanti, D. 2012. Pliocene Mediterranean foraminiferal biostratigraphy: A synthesis and application to palaeoevironmental evolution of northwestern Italy.
Stratigraphic Analysis of Layered Deposits (ed. Ömer, E.). In: Techopen, Rijeka, available at: http:/www.intechopen. com/books/stratigraphicanalysis-of-layered-deposits/ pliocene-mediterranean-foraminiferl-biostratigraphy-asynthesis-and-applicationto-the-paleoenviro.

Wade, B.S., Pearson, P.N., Berggren, W.A. \& Pälike, H. 2011. Review and revision of Cenozoic tropical planktonic foraminiferal biostratigraphy and calibration to the geomagnetic polarity and astronomical time scale. Earth-Science Reviews, 104, 111-142; doi: 10.1016/j. earscirev.2010.09.003.

Wisshak, M. 2006. High-Latitude Bioerosion. The Kosterfjord Experiment. Lectures Notes in Earth Sciences, 109. Springer-Verlag, Berlin. 202 pp.

Zotano, J.G. 2003. Aproximación geomorfológica al karst de la Sierra de la Utrera (provincia de Málaga). Baetica. Estudios de Arte, Geografia e Historia, 25, 137-158. 
